\title{
FORMULASI SALEP EKSTRAK METANOL DAUN SRIKAYA (Annona squamosa L) DENGAN BERBAGAI VARIASI BASIS
}

\author{
A. Muflihunna, Hediyanti Lating \\ Fakultas Farmasi Universitas Muslim Indonesia \\ Email : amchund124@gmail.com
}

\begin{abstract}
This research methanol extract srikaya leaf performed to formulate ointments in bases variation that were hydrocarbon base, absorption base, water-soluble and emultion base. The aim was to determine which one the most stable base contain the methanol extract srikaya leaf. Stability evaluation maked in two condition were before and after stress condition at $5^{\circ} \mathrm{C}-35^{\circ} \mathrm{C}$ for 10 cycles, by which the parameters were organoleptic observation, viscosity measurement, and yield value determination. Result of organoleptic showed that there was not alteration in color, smell, and consistency of those four bases, before and after stress conditioned. Statistyc data analyse of viscosity measurement showed that formula in absorption base was the stable one due to no alteration before and after accelerated condition. Yield value showed that there was thixotrophy plastic flowing exhibited by rheogram. And of those four formula ointment types of methanol extract srikaya leaf (Annona squamosa L) that have been made in, absorption base was the most stability optimum base.
\end{abstract}

Key words : Srikaya Leaf, Formulation, Ointments

\section{PENDAHULUAN}

Menurut Dalimarta (2003), Srikaya adalah tanaman berkhasiat yang dapat digunakan sebagai obat Bagian tanaman yang dapat digunakan sebagai obat yaitu daun, akar, buah, kulit kayu, dan biji. Daunnya digunakan untuk mengatasi demam, diare, anthelmintik, luka, kudis, serta mempercepat pemasakan bisul dan abses. Hasil penelitian sebelumnya (Arianty Ella,2005) menunjukkan bahwa ekstrak metanol daun Srikaya (Annona squamosa L.) memiliki aktivitas antimikroba terhadap bakteri Staphylococcus aureus dan dapat menghambat pertumbuhannya pada konsentrasi $1 \%$.

Salep adalah sediaan semipadat yang dimaksudkan untuk penggunaan luar pada kulit atau membran mukosa, melebur pada suhu tubuh, mudah digunakan dan tidak berpasir (Allen, 1998).

Berdasarkan hal diatas, maka ekstrak metanol daun srikaya (Annona 
squamosa L) berpotensi untuk dibersihkan, dikeringkan dan diformulasi dalam bentuk sediaan dipotong-potong kecil dan salep kulit dari, karena penggunaan bentuk sediaan ini lebih praktis dan mudah dibandingkan bentuk sediaan lain (Gennaro, 1990).

\section{METODE PENELITIAN}

\section{A. Pembuatan Ekstrak}

Sampel daun srikaya selanjutnya diekstraksi.

Sampel ditimbang sebanyak 500 gram dimaserasi dengan metanol secukupnya selama 5 hari. Ekstrak cair yang diperoleh diuapkan hingga diperoleh ekstrak (Annona squamosa L) yang telah kental.

\section{Rancangan formula}

Tabel 1. Rancangan Formula Salep Ekstrak Metanol Daun Srikaya (Annona squamosa L) Dengan Berbagai Variasi Basis.

\begin{tabular}{clcccc}
\hline \multirow{2}{*}{ No. Bahan } & & \multicolumn{4}{c}{ Konsentrasi (\%) } \\
\cline { 3 - 6 } & & A & B & C & D \\
\hline 1 & Ekstrak metanol & 5 & 5 & 5 & 5 \\
2 & a-tokoferol & 0.001 & 0.001 & 0.001 & 0.001 \\
3 & Cera alba & 3 & 5 & - & 5 \\
4 & Lanolin anhidrat & - & 3 & - & - \\
5 & Metil Paraben & - & - & - & 0.02 \\
6 & Natrium lauril sulfat & - & - & - & 2 \\
7 & Propil paraben & 0.01 & 0.01 & 0.01 & 0.01 \\
8 & Propilen glikol & - & - & - & 5 \\
9 & PEG 400 & - & - & 72 & - \\
10 & PEG 4000 & - & - & 23 & - \\
11 & Setil alkohol & - & 1 & - & 10 \\
12 & Vaselin putih & 92 & 86 & - & - \\
13 & Air suling & - & - & - & ad 100 \\
\hline
\end{tabular}

\section{Keterangan:}

A: Basis Hidrokarbon

B: Basis Absorpsi

C: Basis Larut air

D: Basis Emulsi

B. Pembuatan salep

\section{a. Basis hidrokarbon}

1. Salep dibuat dengan menggunakan metode peleburan

2. Cera alba dipanaskan hingga melebur, di tambahkan propil paraben, vaselin putih lalu diaduk hingga homogen

3. Setelah dingin dan memadat, basis kemudian ditambahkan a-tokoferol dan ekstrak metanol daun 
srikaya, kemudian digerus hingga homogen.

\section{b. Basis absorpsi}

1. Salep dibuat dengan menggunakan metode peleburan

2. Cera alba, setil alkohol, vaselin putih, propil paraben dan lanolin dipanaskan hingga lebur dan diaduk hingga homogen, kemudian diangkat dari penangas dan didinginkan.

3. Basis yang telah homogen ditambahkan dengan alfa tokoferol dan ekstrak metanol daun srikaya lalu gerus hingga homogen.

\section{c. Basis larut air}

1. Salep dibuat dengan menggunakan metode peleburan

2. Polietilen glikol 4000 dipanaskan hingga melebur dan ditambahkan polietilen glikol 400 hingga terbentuk massa yang kental kemudian ditambahkan propil paraben dan aduk hingga homogen lalu didinginkan.

3. Basis yang telah homogen ditambahkan dengan alfa tokoferol, setelah itu dimasukkan ekstrak metanol daun srikaya lalu digerus hingga homogen.

\section{d. Basis emulsi $\mathrm{m} / \mathrm{a}$}

1. Salep ini tediri dari dua fase yaitu fase minyak dan fase air.

2. Fase minyak dibuat dengan cara melebur berturut-turut setil alkohol, cera alba, alfa tokoferol dan propil paraben

3. Fase air dibuat dengan mencampurkan air suling yang dipanaskan dengan natrium lauril sulfat, propilen glikol dan metil paraben

4. Fase minyak ditambahkan ke dalam fase air sambil diaduk sampai terbentuk emulsi. Basis yang telah homogen ditambahkan ekstrak metanol daun srikaya lalu digerus hingga homogen.

\section{Evaluasi kestabilan}

Evaluasi kestabilan dari sediaan salep ekstrak metanol daun srikaya (Annona squamosa $\mathrm{L}$ ) dengan empat jenis basis yang dilakukan sebelum dan setelah penyimpanan dipercepat. Penyimpanan dipercepat dilakukan pada suhu antara $5^{\circ} \mathrm{C}$ dan $35^{\circ} \mathrm{C}$, 
masing-masing 12 jam selama 10 siklus (Banker,1995).

a. Pemeriksaan organoleptis.

Pemeriksaan organoleptis meliputi warna, konsistensi dan bau sediaan salep yang dilakukan sebelum dan setelah penyimpanan dipercepat.

b. Pengukuran viskositas.

Pengukuran viskositas menggunakan viskometer
Brookfield dengan spindel no.64 pada kecepatan 50 putaran per menit (rpm).

c. Penentuan nilai yield.

Sifat aliran ditentukan dengan membuat grafik hubungan antara shearing stress (tekanan geser) dan rate of shear (kecepatan geser). Tekanan geser dinyatakan dalam dyne $\mathrm{cm}^{-2}$ sedangkan kecepatan geser dinyatakan dalam putaran per menit (rpm).

\section{HASIL PENELITIAN}

Tabel 2. Hasil Pengamatan Organoleptis Sebelum dan Setelah Penyimpanan Dipercepat.

\begin{tabular}{llll}
\hline \multirow{2}{*}{ Jenis Sediaan } & \multirow{2}{*}{ Jenis Pemeriksaan } & \multicolumn{2}{c}{ Kondisi } \\
\cline { 3 - 4 } Basis & Bau & Khas Aromatis & Khas Aromatis \\
Hidrokarbon & Warna & Hijau kecoklatan & Hijau kecoklatan \\
& Konsistensi & Halus kaku & Halus kaku \\
\hline \multirow{2}{*}{ Basis } & Bau & Khas Aromatis & Khas Aromatis \\
Absorpsi & Warna & Hijau kecoklatan & Hijau kecoklatan \\
& Konsistensi & Halus & Halus \\
Basis & Bau & Khas Menyengat & Khas Menyengat \\
Larut air & Warna & Coklat kehitaman & Coklat kehitaman \\
& Konsistensi & Halus agak encer & Halus agak encer \\
Basis & Bau & Khas aromatis & Khas Aromatis \\
Emulsi m/a & Warna & Hijau Muda & Hijau Muda \\
& Konsistensi & Halus & Halus \\
\hline
\end{tabular}


Tabel 3. Hasil Pengukuran Rata-rata Viskositas Salep Ekstrak Metanol Daun Srikaya (Annona squamosa L) Sebelum dan Setelah Penyimpanan dipercepat .

\begin{tabular}{ccccc}
\hline Kondisi & Formula A (Poise) & Formula B (Poise) & Formula C (Poise) & Formula D (Poise) \\
\hline Sebelum & 94.633 & 51.633 & 197.067 & 56.567 \\
Setelah & 37.367 & 44.133 & 116.967 & 11.033 \\
\hline
\end{tabular}

Tabel 4. Hasil Pengujian Rata-rata Nilai Yield Salep Ekstrak Metanol Daun Srikaya (Annona squamosa L) Sebelum dan Setelah Penyimpanan dipercepat .

\begin{tabular}{ccccc}
\hline Kondisi & Formula A (Poise) & Formula B (Poise) & Formula C (Poise) & Formula D (Poise) \\
\hline Sebelum & 16.905 & 15.741 & 20.43 & 6.1335 \\
Setelah & 11.94 & 13.702 & 44.146 & 4.502 \\
\hline
\end{tabular}

\section{PEMBAHASAN}

Penelitian ini dilakukan untuk menentukkan jenis basis salep yang dapat menghasilkan sediaan salep ekstrak metanol daun srikaya (Annona squamosa L) yang memiliki kestabilan optimal.

Penelitian ini menggunakan empat jenis basis salep yaitu basis hidrokarbon, basis absorpsi, basis larut air, dan basis emulsi. Formula dengan basis salep hidrokarbon terdiri dari cera alba dan vaselin putih, basis ini tidak mudah jadi tengik, tidak mengiritasi kulit, tidak reaktif dengan bahan obat, melindungi dan menghaluskan kulit, dan tidak berubah dalam waktu cepat,. Formula dengan basis salep absorpsi menggunakan bahan tambahan yakni cera alba, vaselin putih, $\alpha$-tocoferol, lanolin anhidrat. Lanolin mengandung air antara $25-30 \%$, sangat cepat dan mudah diabsorpsi untuk kulit karena karakter dan komposisinya mirip dengan asam lemak yang di sekresi oleh kelenjar sebaseus. Setil alkohol sebagai emolien untuk mempertinggi kestabilan, memperbaiki tekstur, dan meningkatkan kekentalan.

Untuk formula dengan basis larut dalam air di gunakan a-tocoferol, propil paraben, PEG 400 dan PEG 4000. Kombinasi dari PEG dengan bobot molekul yang tinggi dan PEG dengan bobot molekul yang rendah akan menghasilkan produk dengan konsistensi seperti salep yang melunak atau meleleh kulit. Formula dengan basis emulsi di pakai cera alba, setil alcohol, a-tocoferol, dan propil paraben sebagai fase minyak. Air suling, natrium lauril sulfat, propilen glikol, dan metil paraben sebagai fase air. Dimana propilen glikol pada fase air di gunakan sebagai humektan dan natrium lauril sulfat sebagai emulgator yang berfungsi untuk menurunkan 
tegangan antar muka antara dua cairan.

Sediaan salep dievaluasi kestabilan yang meliputi pemeriksaan organoleptis, pengukuran viskositas, dan penentuan nilai yield sebelum dan sesudah penyimpanan di percepat. Pengujian kestabilan dilakukan dengan metode kondisi di paksakan (stress condition) dengan penyimpanan pada suhu $5^{\circ} \mathrm{C}$ dan $35^{\circ} \mathrm{C}$ selama 10 siklus, kedua siklus ini berdurasi 12 jam. Tujuan dilakukannya kondisi dipaksakan (penyimpanan dipercepat) adalah untuk mempercepat proses penguraian dari bahan-bahan dan untuk mempersingkat waktu pengujian.

Pada pemeriksaan organoleptis dari keempat formula salep ekstrak metanol daun srikaya (Annona squamosa L) sebelum dan setelah penyimpanan dipercepat tidak mengalami perubahan warna, bau, dan konsistensi sehingga dapat disimpulkan bahwa keempat sediaan salep stabil secara fisika. Pengukuran viskositas pada sediaan salep ekstrak metanol daun srikaya (Annona squamosa $\mathrm{L}$ ) dilakukan menggunakan alat viskometer Brookfield. Data hasil pengukuran viskositas dianalisa secara statistik menggunakan metode Rancangan Acak Kelompok". Hasil analisis menunjukkan bahwa viskositas formula II (basis absorpsi) lebih stabil karena pada kondisi sebelum dan setelah penyimpanan dipercepat tidak berbeda nyata atau non signifikan .

Uji kestabilan salep ekstrak metanol daun srikaya (Annona squamosa L) yang dilakukan adalah penentuan nilai yield. Nilai yield adalah besarnya gaya yang diperlukan sehingga salep dapat mengalir ketika dikeluarkan dari tube. Nilai yield dihitung dari pengukuran viskositas sediaan pada beberapa rpm, kemudian dari data yang diperoleh dapat ditentukan tekanan geser (Shearing stress) dan kecepatan geser (Rate of shear). Sifat aliran ditentukan dengan membuat grafik hubungan antara tekanan geser (Shearing stress) dan kecepatan geser (Rate of shear). Analisa data statistik nilai yield di buat dengan melakukan uji lanjutan BNJ. Hasilnya menunjukkan bahwa formula II (basis absorpsi) adalah formula yang paling stabil untuk uji kestabilan karena perbandingan kondisi sebelum dan setelah penyimpanan dipercepat pada penentuan nilai yield tidak mengalami perubahan yang nyata (non signifikan).

Rheogram dari hubungan antara tekanan geser (Shearing 
stress) dan kecepatan geser (Rate of shear) setelah dibuat rheogram, menunjukkan sifat aliran non Newton yaitu aliran plastis yang mempunyai sifat thiksotropi.

\section{KESIMPULAN}

Hasil penelitian dapat disimpulkan bahwa formula yang memiliki kestabilan optimal untuk salep ekstrak metanol daun srikaya (Annona squamosa $\mathrm{L}$ ) adalah formula dengan basis salep absorpsi.

\section{DAFTAR PUSTAKA}

Anief M, 1997,"Formulasi Obat Topikal Dengan Dasar Penyakit Kulit", Gajah Mada University Press, Yogyakarta. 31-32.

Allen L. V, Jr, 1998," The Art Science and Technology of PharmaceuticalCompounding, "American Pharmaceutical Association, Washington DC. 189

Budiono J, 2007," PertimbanganPertimbangan Pemilihan Basis Salep," (Online), http://www.Kalbefarma.com/fil es/12RuangBiofarmasi008.Pd f/12RuangBiofarmasi008. diakses Maret 2008.

Banker, G.S., and Rhodes, C.T., 1995,"Modern

Pharmaceutics," Third Edition, Marcel Dekker, Inc., New York. 323

Dalimarta, S., 2003,"Atlas Tumbuhan Obat Indonesia," Jilid 3. Trubus Agriwidya, Jakarta. 82-85
Djuanda A., 1999,"IImu Penyakit Kulit dan Kelamin, Edisi ketiga, Balai Penerbit FKU 1, Universitas Indonesia, Jakarta. 3,4.

Ditjen POM, 1979.,"Farmakope Indonesia," Edisi III, Direktorat Jenderal Pengawasan Obat dan Makanan, Jakarta 96, 140, 378, 504, 535, 633.

Ella Arianty., 2005,"Uji Aktivitas Antimikroba Ekstrak Metanol Daun Srikaya (Annona squamosa L) Terhadap Staphylococcus aureus," Universitas Muslim Indonesia, Makassar. 24

Gennaro. A.R., 1990,"Remington's Pharmaceutical Sciences, 18 th Edition, Mack Publishing Company, Easton, Pennsylvania. 1534

Graham-Brown. Robin, and Tony Burns., 2002,"Dermatologi," Edisi Kedelapan, Penerbit Erlangga, Jakarta. 20-21

Heyne. K., 1987,"Tumbuhan Berguna Indonesia," Edisi II, Badan Litbang, Departemen Kehutanan, Jakarta. 1457

Hariana, Arief. H.,2008,"Tumbuhan Obat dan Khasiatnya," Seri 3, Penerbit Penebar Swadaya, Jakarta. 5

Jenkins. Glen, 1957,"Scoville's The Art of Compounding, Ninth Edition, The Blackkiston Division, Mc Graww Hill Book, Company. Inc. New York, Toronto. London. 338-339

Kibbe, A.H., 2000,"Handbook Of Pharmaceutics Excipient, 
Three Edition, American Pharmaceutical Press, USA.

Lachman Leon, 1986," Teori dan Praktek Farmasi Industri II," Penerbit Universitas Indonesia Press, Jakarta. 1112-1119.

Lund W (Editor), 1994,"The Pharmaceutical Codex. $12^{\text {th }}$ edition, Principles and practice of pharmaceutics, The Pharmaceutical Press, London. 135

Martin A., 1993,"Farmasi Fisik," Edisi ketiga, Penerbit Universitas Indonesia Press, Jakarta. 1091

Sprowls J.B, 1960,"American Pharmacy, Text Book Of
Pharmaceutical Principles Processes \& Preparation, $5^{\text {th }}$ Edition B. Lippincott Company, Philadelphia Montreal. 335-336

Sprowls J.B., 1970,"Prescription Pharmacy, Dosage Formulation Pharmaceutical adjuncts, Second Edition J.B. Lippincott Company, Philadelphia Toronto. 230

Tjitrosoepomo Gembong, 1994, Taksonomi Tumbuhan ObatObatan, Gadjah Mada University Press. Yogyakarta.

Warisno Kres Dahana., 2007,"Budi Daya Srikaya," Penerbit Aneka Ilmu. Semarang. 1, 29. 